\title{
AOR
}

Selected Papers of \#AolR2019:

The $20^{\text {th }}$ Annual Conference of the Association of Internet Researchers Brisbane, Australia / 2-5 October 2019

\section{CRITICAL PEDAGOGIES IN INTERNET STUDIES: TEACHING FOR CHANGE}

Sky Croeser

Curtin University

\begin{abstract}
:
There are urgent reasons for considering whether, as academics, we place our trust in the current system or whether we try to change it. Research offers one pathway towards supporting efforts for positive change, but we should not neglect the potential of our teaching work. Academics within Internet studies have unique possibilities for engaging in critical pedagogies, supporting students in understanding and challenging oppression. I draw here on ten years' experience teaching in Internet studies, student and peer feedback, and the literature on critical pedagogy and decolonizing academia. I suggest that where possible we reflect on the texts we set students; redesign assessment; considering being vulnerable with students; and challenge restrictive policies and procedures (such as those around late submission of assignments). These approaches rely on trusting students, and on building their trust in us without relying solely on our institutional authority. As a field we need to actively and explicitly discuss how, and what, we teach.
\end{abstract}

\section{Internet Studies and the Potential for Critical Pedagogies}

We urgently need teaching practices that unsettle academia. Our social, political, economic, and environmental situation is increasingly dire, characterized by backlashes against queer, feminist and anti-racist movements; rising inequality; and limited action on climate change. We cannot trust that the current system is the best we can hope for. Academics need to decide whether we will use our positions to perpetuate the status quo or to work towards decolonization, more diverse and inclusive societies, more directly democratic political systems, and a more sustainable economic system. Research has a role to play here, but we must not neglect the power of teaching as a path to creating change. The aim of this paper is to suggest ways in which we might

Suggested Citation (APA): Croeser, Sky. (2019, October 2-5). Critical pedagogies for Internet Studies. Paper presented at AoIR 2019: The $20^{\text {th }}$ Annual Conference of the Association of Internet Researchers. Brisbane, Australia: AolR. Retrieved from http://spir.aoir.org. 


\section{AOR}

Selected Papers of \#AoIR2019: The $20^{\text {th }}$ Annual Conference of the Association of Internet Researchers Brisbane, Australia / 2-5 October 2019

support and extend teaching methods that encourage students to understand and challenge oppression - critical pedagogies (Breuing 2011) - within Internet studies.

There are two factors that open Internet studies to the possibility of transformative teaching practices. The first of these is that teaching about the Internet frequently requires - or at least encourages - practices that make use of the Internet.

Unfortunately, as many of us are well aware, the use of the Internet in teaching is frequently linked to top-down policies that mandate the use of digital technologies to 'increase productivity', usually through centralized learning management systems and ever-expanding surveillance of academic labour (Fernback 2018). However, in order to teach students more about how the Internet works, some teachers are designing assessments that require using online tools and actively reflecting on their experiences (see, for example, Tay and Allen 2011; Di Lauro \& Johinke 2016). Fairly early on, some teachers were already arguing for the benefits of carefully-facilitated collaborative learning networks (Hiltz 1998). These efforts have the advantage of connecting academic analysis with practical skills that can be used by students beyond academia hopefully in critical and reflexive ways.

The second factor that encourages critical pedagogies is that Internet studies is a relatively new field: just over a decade ago, there was speculation about whether it should be considered a discipline at all (Baym 2005). Some early reflections argued against the temptation to seek increasing institutionalization, suggesting instead that we attempt to sustain the field's "deliberately unruly, flexibly, and transformative" nature (Markham 2005, 257). Much has happened to solidify Internet studies over recent years, including the growing prominence of the AoIR conference and the gradual emergence of a canon and leadership structure. Charles Ess and Mia Consalvo write that by 2007, "Internet studies had emerged as a relatively stable field of academic study" $(2011,2)$. However, attempts to define the field have frequently focused far more closely on research - including methodologies and ethical guidelines - than on teaching. While there is extensive writing, debate, and established practice on how to teach with the Internet, there has been less attention to how we teach about the Internet. This means that there is still significant room within the teaching of Internet studies for beautiful, diverse, unruliness.

Suggested Citation (APA): Croeser, Sky. (2019, October 2-5). Critical pedagogies for Internet Studies. Paper presented at AoIR 2019: The $20^{\text {th }}$ Annual Conference of the Association of Internet Researchers. Brisbane, Australia: AolR. Retrieved from http://spir.aoir.org. 


\section{AOR}

Selected Papers of \#AolR2019: The $20^{\text {th }}$ Annual Conference of the Association of Internet Researchers Brisbane, Australia / 2-5 October 2019

\section{Methodology}

This paper reflects on a decade of work teaching Internet studies under employment conditions spanning from sessional (short-term) tutoring through to a permanent position. I have taught more than ten Internet studies units, designed one unit and radically updated others. Overlapping teaching semesters mean this work encompasses more than fifty individual unit iterations overall, many of which included both undergraduate and postgraduate teaching. As well as my own experiences I draw on student and peer feedback, analyzing this through the lens of work by Paulo Freire (1972); bell hooks (2013); Clelia Rodríguez (2018); Sara Ahmed (2012); Aileen Moreton-Robinson (2000) and Heila Lotz-Sisitka (2017).

\section{Pathways and Challenges}

In order to be effective, critical pedagogies must be diverse, context-dependent, and reflexive. The pathways which have seemed most useful to me may not be available to others, or may produce very different results. The institutional and imaginative constraints that have led to gaps between my intentions and my practices may be more or less applicable to others. With this in mind, I make several suggestions for critical teaching practices we might encourage within Internet studies.

The most obvious way to disrupt existing hierarchies within academia is in the readings we set in the syllabus. There is no research that focuses specifically on Internet studies, but research in other fields suggests that non-white scholars are cited less than white scholars (Chakravartty et al. 2018) and that people with names read as female are cited less often than people with names read as male (Mitchell et al. 2013). We should assign more diverse readings, even (especially!) if it means reconceptualising how we think about core concepts.

There are several other interventions we might make, including redesigning assessment; being willing to be vulnerable with students; and challenging restrictive policies and procedures (such as those around late submission of assignments). These rely on trusting students, and on building their trust in us without relying solely on our institutional authority. In detailing my experiences with these tactics, I am hopeful that others will add their own analysis, and that we might end up with a living document akin

Suggested Citation (APA): Croeser, Sky. (2019, October 2-5). Critical pedagogies for Internet Studies. Paper presented at AoIR 2019: The $20^{\text {th }}$ Annual Conference of the Association of Internet Researchers. Brisbane, Australia: AolR. Retrieved from http://spir.aoir.org. 


\section{AOR}

Selected Papers of \#AolR2019:

The $20^{\text {th }}$ Annual Conference of the Association of Internet Researchers Brisbane, Australia / 2-5 October 2019

to the AoIR research ethics guidelines (Markham \& Buchanan 2012). As a field, we will benefit from more actively organizing around how, and what, we teach.

\section{References}

Ahmed, S. (2012). On Being Included: Racism and Diversity in Institutional Life. Duke University Press.

Baym, N. K. (2005). Introduction: Internet Research as It Isn't, Is, Could Be, and Should Be. The Information Society, 21(4), 229-232. https://doi.org/10.1080/01972240591007535

Breuing, M. (2011). Problematizing Critical Pedagogy. The International Journal of Critical Pedagogy, 3(3). Retrieved from http://libjournal.uncg.edu/ijcp/article/view/246

Chakravartty, P., Kuo, R., Grubbs, V., \& Mcllwain, C. (2018). \#CommunicationSoWhite. Journal of Communication, 68(2), 254-266. https://doi.org/10.1093/joc/jqy003

Di Lauro, F. \& Johinke, R. (2017). Employing Wikipedia for good not evil: innovative approaches to collaborative writing assessment. Assessment \& Evaluation in Higher Education, 42(3), 478-491. https://doi.org/10.1080/02602938.2015.1127322

Ess, C., \& Consalvo, M. (2011). Introduction: What is "Internet Studies"? In The Handbook of Internet Studies (pp. 1-8). John Wiley \& Sons, Ltd. https://doi.org/10.1002/9781444314861.ch

Fernback, J. (2018). Academic/Digital Work: ICTs, Knowledge Capital, and the Question of Educational Quality. TripleC: Communication, Capitalism \& Critique, 16(1), 143-158. https://doi.org/10.31269/triplec.v16i1.878

Freire, P. (1972). Pedagogy of the oppressed. Harmondsworth: Penguin Books.

Lotz-Sisitka, H. (2017). Decolonisation as future frame for environmental and sustainability education: embracing the commons with absence and emergence. In P.

Suggested Citation (APA): Croeser, Sky. (2019, October 2-5). Critical pedagogies for Internet Studies. Paper presented at AoIR 2019: The $20^{\text {th }}$ Annual Conference of the Association of Internet Researchers. Brisbane, Australia: AolR. Retrieved from http://spir.aoir.org. 


\section{AOR}

Selected Papers of \#AolR2019:

The $20^{\text {th }}$ Annual Conference of the Association of Internet Researchers Brisbane, Australia / 2-5 October 2019

B. Corcoran, J. P. Weakland, \& A. E. J. Wals (Eds.), Envisioning futures for environmental and sustainability education (pp. 45-62). Wageningen, Netherlands: Wageningen Publishers.

Hiltz, S. R. (1998). Collaborative Learning in Asynchronous Learning Networks. Presented at the Web98, Orlando, Florida. Retrieved from https://web.njit.edu/ hiltz/collaborative_learning_in_asynch.htm

hooks, bell. (2013). Teaching Critical Thinking: Practical Wisdom (1st ed.). Hoboken: Taylor and Francis.

Markham, A. N. (2005). Disciplining the Future: A Critical Organizational Analysis of Internet Studies. The Information Society, 21(4), 257-267. https://doi.org/10.1080/01972240591007571

Markham, A., \& Buchanan, E. (2012). Ethical decision-making and Internet research 2.0: Recommendations from the AolR ethics working committee. Retrieved from https://aoir.org/ethics/

Mitchell, S. M., Lange, S., \& Brus, H. (2013). Gendered Citation Patterns in International Relations Journals. International Studies Perspectives, 14(4), 485-492.

https://doi.org/10.1111/insp.12026

Moreton-Robinson, A. (2000). Talkin' Up to the White Woman: Aboriginal Women and Feminism. Univ. of Queensland Press.

Rodríguez, C. O. (2018). Decolonizing Academia: Poverty, Oppression and Pain. Halifax \& Winnipeg: Fernwood Books Ltd.

Tay, E., \& Allen, M. (2011). Designing social media into university learning: technology of collaboration or collaboration for technology? Educational Media International, 48(3), 151-163. https://doi.org/10.1080/09523987.2011.607319

Suggested Citation (APA): Croeser, Sky. (2019, October 2-5). Critical pedagogies for Internet Studies. Paper presented at AoIR 2019: The $20^{\text {th }}$ Annual Conference of the Association of Internet Researchers. Brisbane, Australia: AolR. Retrieved from http://spir.aoir.org. 